\title{
WHAT SHALL WE DO WITH THE DISHONEST FIDUCIARY? THE UNPREDICTABILITY OF ALLOWANCES FOR WORK AND SKILL
}

\author{
BRONWYN ARNOLD*
}

\begin{abstract}
Fiduciaries who breach their obligations by making a profit may apply to the courts for an allowance for the work and skill that generated the profit, but it is unclear whether a court will indulge the application if the fiduciary's breach was tainted with dishonesty. There are two different approaches available to the courts when faced with a dishonest fiduciary applying for an allowance. Courts that choose the first approach will rely on Boardman $\mathrm{v}$ Phipps and award an allowance that reflects the fiduciary's conduct. Courts that follow the second approach will ignore the fiduciary's dishonesty by relying on Warman International Ltd $\mathrm{v}$ Dwyer, and will award an allowance to prevent the principal's unjust enrichment. The availability of the two different approaches has resulted in inconsistent outcomes and confusion in the law. This article explores the justifications for adopting each of the available approaches whenever a dishonest fiduciary applies for an allowance. Part I outlines the progression of the case law since Boardman $\mathrm{v}$ Phipps. Part II describes the rationales for adopting each of the approaches to awarding allowances to dishonest fiduciaries. It concludes that the conduct-based approach in Boardman v Phipps should be rejected, and that the unjust enrichment-based approach provided by Warman International Ltd v Dwyer should be adopted by the courts when awarding allowances to defaulting fiduciaries.
\end{abstract}

\section{CONTENTS}

The Treatment of Dishonesty: Boardman and Beyond. 3

A Fiduciary Relationships ....................................................... 3

B Allowances: The Treatment of Dishonesty in the Case Law.... 4

II Justifying and Adopting an Approach: The Available Options . 13

A Dishonesty Approach Option One: Refusing Allowances...... 13

B Dishonesty Approach Option Two: Reducing Allowances .... 16

C Option Three: Allowances to Prevent Unjust Enrichment ..... 17

III

Conclusion

* $\quad$ LLB student, School of Law, University of South Australia. 


\section{INTRODUCTION}

It is indisputable that any fiduciary who breaches their obligations by making a profit will be made to account for that profit. ${ }^{1}$ However, the issue of whether they should be paid for the work that generated the profit is far more contentious. At present, when a dishonest fiduciary applies for an allowance, the courts can choose from two different approaches to resolve the matter. Courts choosing the first approach rely on the Boardman $v$ Phipps ('Boardman') ${ }^{2}$ line of authority, which reduces or refuses allowances depending on the degree of dishonesty. The first approach from Boardman is referred to in this article as the 'dishonesty approach'. Courts following the second approach rely on Warman International Ltd $v$ Dwyer ('Warman'), ${ }^{3}$ and award allowances according to the work and skill that generated the profit. The second approach from Warman is referred to in this article as the cunjust enrichment approach'. The availability of these different approaches has resulted in inconsistent outcomes and confusion in the law. This article addresses the confusion by examining the justifications for each of the approaches and argues that the High Court of Australia should reject the dishonesty approach entirely, and adopt the unjust enrichment approach.

This article focuses on profits made by fiduciaries who misuse their position, ${ }^{4}$ rather than on profits made by fiduciaries who misuse the principal's property. This is because when profits are made by the fiduciary misusing their position (for example, by exploiting a business opportunity that should have been afforded to the principal), ${ }^{5}$ the resultant profits can be attributed to the fiduciary's efforts; whereas profits made from the exploitation of the principal's property are attributable to the property itself. ${ }^{6}$ In the latter case, it

Bray v Ford [1896] AC 44, 51-2 (Lord Herschell); Regal (Hastings) Ltd v Gulliver [1967] 2 AC 134, 137 (Viscount Sankey), 144-5 (Lord Russell), 153 (Lord Macmillan).

$2 \quad$ Phipps v Boardman [1964] 1 WLR 993 (Court of Chancery); Boardman v Phipps [1965] Ch 992 (Court of Appeal); Boardman v Phipps [1967] 2 AC 46 (House of Lords).

3 (1995) 182 CLR 544

4 Also known as 'non-specific assets': See Jessica Palmer, 'The Availability of Allowances in Equity: Rewarding the Bad Guy' (2004) 21 New Zealand Universities Law Review 146, 162; Warman International Ltd v Dwyer (1995) 182 CLR 544, 561.

5 See, eg, Victoria University of Technology v Wilson (2004) 60 IPR 392.

6 Warman International Ltd v Dwyer (1995) 182 CLR 544, 561-2. But see Palmer, above n 4, $162-3$. 
is unlikely that the courts would award an allowance because the fiduciary has exposed the principal's property to the risk of depreciation. ${ }^{7}$

Part I of the article provides general information about fiduciary relationships. It also examines the progression of some of the case law to demonstrate the different ways that courts have treated the issue of dishonesty when assessing allowances. It shows that the courts recognise the availability of the two approaches, and points out that no clear judicial reasons are given for preferring one approach over the other. Part II explains the available options for assessing allowances and examines the justifications for adopting each of the different approaches. The article concludes that the best approach for awarding allowances is to ignore the fiduciary's dishonesty and instead focus on the value of the work done in generating the profit.

\section{ThE TREATMENT OF DishoneSTY: BOARDMAN ${ }^{8}$ AND BEYOND}

\section{A Fiduciary Relationships}

Instead of creating a definition of fiduciary relationships, the courts' focus has been on the content of those relationships. ${ }^{9}$ The defining characteristic of all fiduciary relationships is the duty of loyalty. ${ }^{10}$ The duty of loyalty is captured by two proscriptive rules: the 'no conflict' and the 'no profit' rules. ${ }^{11}$ Fiduciaries are bound by these rules and will be in breach if they make a profit either by allowing their personal interests to conflict with their principal's, or

7 Peter Devonshire, 'Account of Profits for Breach of Fiduciary Duty' (2010) 32 Sydney Law Review 389, 406-7; Peter Devonshire, Account of Profits (Thomson Reuters, 2013) 78; J D Heydon, M J Leeming and P G Turner, Meagher, Gummow and Lehane's Equity: Doctrines and Remedies (LexisNexis Butterworths, $5^{\text {th }}$ ed, 2015) 194 [5-280].

8 [1964] 1 WLR 993; [1965] Ch 992; [1967] 2 AC 46.

9 Hospital Products Ltd v United States Surgical Corporation (1984) 156 CLR 41, 96 (Mason $\mathrm{J})$.

10 Bristol \& West Building Society v Mothew [1998] Ch 1, 18 (Millett LJ); Gibson Motorsport Merchandise Pty Ltd v Forbes (2006) 149 FCR 569, 574-5 [12] (Finn J); Paul B Miller, 'Justifying Fiduciary Duties' (2013) 58 McGill Law Journal 969, 977; Lionel Smith, 'Fiduciary Relationships: Ensuring the Loyal Exercise of Judgement on Behalf of Another' (2014) 130 Law Quarterly Review 609-13.

11 Chan v Zacharia (1984) 154 CLR 178, 199 (Deane J); Hospital Products Ltd v United States Surgical Corporation (1984) 156 CLR 41, 67 (Gibbs CJ); Warman International Ltd v Dwyer (1995) 182 CLR 544, 557. 
by misusing their position to gain a personal advantage. ${ }^{12}$ Fiduciaries are held strictly liable for any profits made in breach of these rules. This means that they will be made to account for the profits regardless of whether they acted honestly or mistakenly. ${ }^{13}$ Equity's insistence on strict liability holds the fiduciary to the highest possible standard of behaviour. ${ }^{14}$ Strict liability does not punish the fiduciary, ${ }^{15}$ but forces them to perform their duty by assuming that they always intended to hand over the profit to their principal. ${ }^{16}$

\section{B Allowances: The Treatment of Dishonesty in the Case Law}

Although fiduciaries are not permitted to keep the profits made from a breach of duty, it has long been the law that they may be awarded a 'just allowance' for the work and skill that generated the profits. ${ }^{17}$ Originally, allowances were awarded because it would be inequitable for the principal to accept the benefit of the profit without paying for the work that produced it. ${ }^{18}$ This seemingly straightforward proposition was altered in the 1960 s by the Boardman ${ }^{19}$ line of cases, which introduced the dishonesty approach. This Part examines some of the case law in Australia and England. It identifies the different attitudes to awarding just allowances in cases of dishonesty and shows that there is a

12 Chan v Zacharia (1984) 154 CLR 178, 198-9 (Deane J); Warman International Ltd v Dwyer (1995) 182 CLR 544, 557.

13 Regal(Hastings) Ltd v Gulliver [1967] 2 AC 134, 137 (Viscount Sankey), 144 (Lord Russell); Warman International Ltd v Dwyer (1995) 182 CLR 544, 558.

14 Warman International Ltd v Dwyer (1995) 182 CLR 544, 557.

15 Dart Industries Inc v Décor Corporation Pty Ltd (1993) 179 CLR 101, 114-15 (Mason CJ, Deane, Dawson and Toohey JJ), 123 (McHugh J); Warman International Ltd v Dwyer (1995) 182 CLR 544, 557. Cf Bray v Ford [1896] AC 44, 51 (Lord Herschell); Consul Development Pty Ltd v D P C Estates Pty Ltd (1975) 132 CLR 373, 397 (Gibbs J); Devonshire, 'Account of Profits', above n 7, 58-9 [3.3.3], 59 [3.3.4]; Sir Peter Millett, 'Bribes and Secret Commissions Again' (2012) 71(3) Cambridge Law Journal 583, 590.

16 Smith, above n 10, 628-9; Millett, above n 15, 591-2, 600; Paul B Miller, 'Justifying Fiduciary Remedies' (2013) 63(4) University of Toronto Law Journal 570, 572-3. See also Matthew Doyle, 'Corrective Justice and Unjust Enrichment' (2012) 62 University of Toronto Law Review 229, 230, 247; Charles Rickett, 'Understanding Remedies for Breach of Trust' (2008) 11(4) Otago Law Review 603, 604, 610-11, 616.

17 See, eg, Re Jarvis; Edge v Jarvis [1958] 1 WLR 815, 820; Heydon, Leeming and Turner, above $n$ 7, 190-7 [5-280].

18 Re Macadam; Dallow v Codd [1946] Ch 73, 82-3; Re Jarvis; Edge v Jarvis [1958] 1 WLR 815, 820. See also Heydon, Leeming and Turner, above n 7, 190-7 [5-280].

19 [1964] 1 WLR 993; [1965] Ch 992; [1967] 2 AC 46. 
divergence between the approaches taken by Australian judges, who generally award allowances, and the English judges, who rarely award them. ${ }^{20}$

The Boardman line of cases arose when a testator, Charles Phipps, left property on trust for his four children, one of whom was Tom Phipps, who was also the second defendant. Boardman was the solicitor to the trust. Part of the trust property included shares in a particular company. Boardman thought that the company could be made more profitable if its affairs were to be rearranged. Boardman and Tom Phipps made enquiries about the company on behalf of the trust, and eventually decided to purchase the remaining shares in the company. The trust could not make the purchase, because the trust did not authorise investments of that kind. Boardman and Tom Phipps succeeded in their takeover of the company, and made a substantial profit. Boardman had kept the beneficiaries informed of his actions at all times and had acted with complete honesty throughout. ${ }^{21}$

At first instance, Wilberforce $J$ held that it would be inequitable for a principal to accept the benefit of the profit, "without paying for the skill and labour which has produced it'. ${ }^{22}$ In the English Court of Appeal, ${ }^{23}$ Lord Denning MR agreed with, and expanded upon, the decision of Wilberforce $\mathrm{J}$ :

Ought Boardman and Tom Phipps to be allowed remuneration for their work and skill in these negotiations?... The gist of it is that the defendant has unjustly enriched himself, and it is against conscience that he should be allowed to keep the money. The claim for repayment cannot, however, be allowed to extend further than the justice of the case demands. If the defendant has done valuable work in making the profit, then the court in its discretion may allow him a recompense. It depends on the circumstances. If the agent has been guilty of any dishonesty or bad faith, or surreptitious dealing, he might not be allowed any remuneration or reward. But when, as in this case, the agents acted openly and above board, but mistakenly, then it would be only just that they should be allowed remuneration. As [Wilberforce J] said: 'it would be inequitable now for the beneficiaries to step in and take the profit without paying for the skill and labour which has produced it.' I think there should be a generous remuneration allowed to the agents. ${ }^{24}$

\footnotetext{
20 Heydon, Leeming and Turner, above n 7, 196-7 [5-280].

$21 \quad$ Phipps v Boardman [1964] 1 WLR 993, 995-1007.

22 Ibid 1018

23. Boardman v Phipps [1965] Ch 992.

24 Ibid 1020-1 (Lord Denning MR).
} 
On appeal to the House of Lords, Lords Cohen and Hodson agreed that the allowance should be paid 'on a liberal scale'. ${ }^{25}$ It follows from the Boardman ${ }^{26}$ line of cases, therefore, that fiduciaries who breach in 'good' faith will be paid, and paid well; and those who breach in 'bad' faith will be paid very little, or not at all. ${ }^{27}$ However, the subsequent case law shows that the courts have not consistently followed the dishonesty approach. Dishonest fiduciaries receive varying treatment by the courts when awarding allowances. ${ }^{28}$

Fifteen years later in Australia, Brinsden $\mathrm{J}$ in the Supreme Court of Western Australia followed Boardman ${ }^{29}$ in Green \& Clara Pty Ltd $v$ Bestobell Industries Pty Ltd [No 2] ${ }^{30}$ when Green applied to the Court for an allowance. In breach of his fiduciary obligations, Green had established a new company, Clara Pty Ltd, for the purpose of securing a tender in direct competition with his employer, Bestobell Industries Pty Ltd. ${ }^{31}$ Brinsden $\mathbf{J}$ asserted that the starting point in assessing allowances was the English Court of Appeal's decision in Boardman. ${ }^{32}$ Any remuneration to which Green may have been entitled was subject to the principle of reducing allowances in accordance with dishonesty. ${ }^{33}$ Brinsden $\mathrm{J}$ used the dishonest nature of Green's breach ${ }^{34}$ to reduce the allowances that Green had previously been awarded. ${ }^{35}$ This reduction was necessary both to punish Green and to deter fiduciaries from acting in the same manner. ${ }^{36}$ The application of the dishonesty approach by

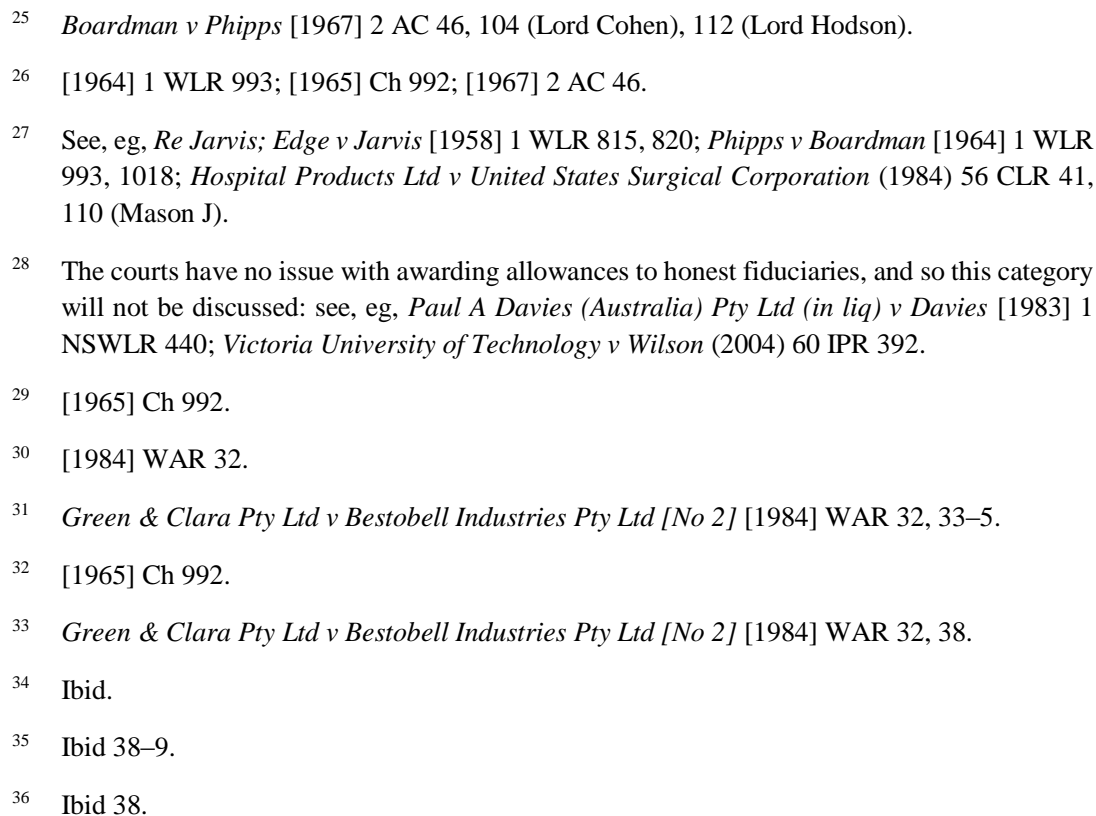


Brinsden $\mathrm{J}$ was consistent with the law at that time; however, different approaches emerged both in England and in Australia in subsequent cases.

The law in England was altered slightly when the Court of Appeal decided O'Sullivan v Management Agency and Music Ltd ${ }^{37}$ in 1985. There, the Court asserted that an outright refusal to award allowances in all cases where the fiduciary breached their obligations would cause substantial injustice to the fiduciary. ${ }^{38}$ Their Lordships went further, and argued that the proposition in Boardman $^{39}$ was too narrow. It was inappropriate to award allowances only to fiduciaries who breached 'in good faith', because courts should seek to do what was practically just in all of the circumstances. The fiduciary's dishonesty was a relevant factor, and could be used to affect the quantum of the allowance, but it was not the deciding factor. If the profit was the result of the fiduciary's work and skill, that work should be recognised through an allowance, even though an element of bad faith was present. ${ }^{40}$

The path in England took another turn in 1990, when the House of Lords decided Guinness plc v Saunders ('Guinness'). ${ }^{41}$ This was a case involving an ostensibly honest breach of fiduciary obligation by a company director, ${ }^{42}$ but no allowance was awarded. Lord Templeman refused an allowance on the basis that the company's articles did not permit its directors to be remunerated, and so the Court would not 'usurp the functions conferred on the board by the articles' ${ }^{43}$ His Lordship also contended that 'exceptional circumstances' may exist that would permit the Court to award an allowance. ${ }^{44}$ Lord Templeman added that Boardman ${ }^{45}$ was a case involving exceptional circumstances, but did not elaborate any further on this point. Lord Goff maintained that

$37 \quad[1985]$ QB 428.

38 Ibid 458-9 (Dunn LJ), 468-9 (Fox LJ), 472-3 (Waller LJ).

39 [1965] Ch 992.

40 O'Sullivan v Management Agency and Music Ltd [1985] QB 428, 458-9 (Dunn LJ), 468-9 (Fox LJ), 472-3 (Waller LJ).

$41 \quad[1990] 2$ AC 663.

42 Guinness plc v Saunders [1990] 2 AC 663, 695 (Lord Templeman), 696 (Lord Goff); cf Kit Barker, 'Riddles, Remedies, and Restitution: Quantifying Gain in Unjust Enrichment Law' (2001) 54(1) Current Legal Problems 255, 301; Struan Scott, 'Rights, Remedies, Wrongs and the Bribe-Taking Fiduciary' in Charles Rickett (ed), Justifying Private Law Remedies (Hart Publishing, 2008) 33, 64.

43 Guinness plc v Saunders [1990] 2 AC 663, 689, 692-3.

44 Ibid 694

45 [1965] Ch 992. 
Boardman $^{46}$ was irreconcilable with the principle that trustees should not be remunerated 'except as expressly provided in the trust deed', ${ }^{47}$ unless the remuneration would not promote a breach of obligation. ${ }^{48}$ His Lordship added that Boardman ${ }^{49}$ was not a case that encouraged a conflict of interest, but did not explain his reasons for so finding. ${ }^{50}$ Guinness $^{51}$ is therefore problematic: first, because Lord Goff did not give reasons why Guinness ${ }^{52}$ but not Boardman ${ }^{53}$ encouraged a conflict of interest; and secondly, because no clear ratio emerges from the case. ${ }^{54}$ Possibly all that can be said about Guinness ${ }^{55}$ is that allowances will be made in England only under exceptional circumstances, although precisely what would constitute exceptional circumstances is unclear. ${ }^{56}$

The High Court of Australia complicated matters in 1995 when, in a unanimous decision, it decided Warman International Ltd v Dwyer. ${ }^{57}$ This was the first High Court case to deal with the question of just allowances. In that case, Dwyer dishonestly breached his fiduciary obligations to Warman International ('Warman'), when, as general manager of Warman's Queensland branch, he actively sought to reduce Warman's business partner's confidence in the company while simultaneously promoting a partnership with his own companies. ${ }^{58}$ Dwyer was given an allowance for his work and skill in establishing and operating the new businesses, ${ }^{59}$ but the High Court did not refer to the dishonest nature of Dwyer's conduct. Indeed, there was no

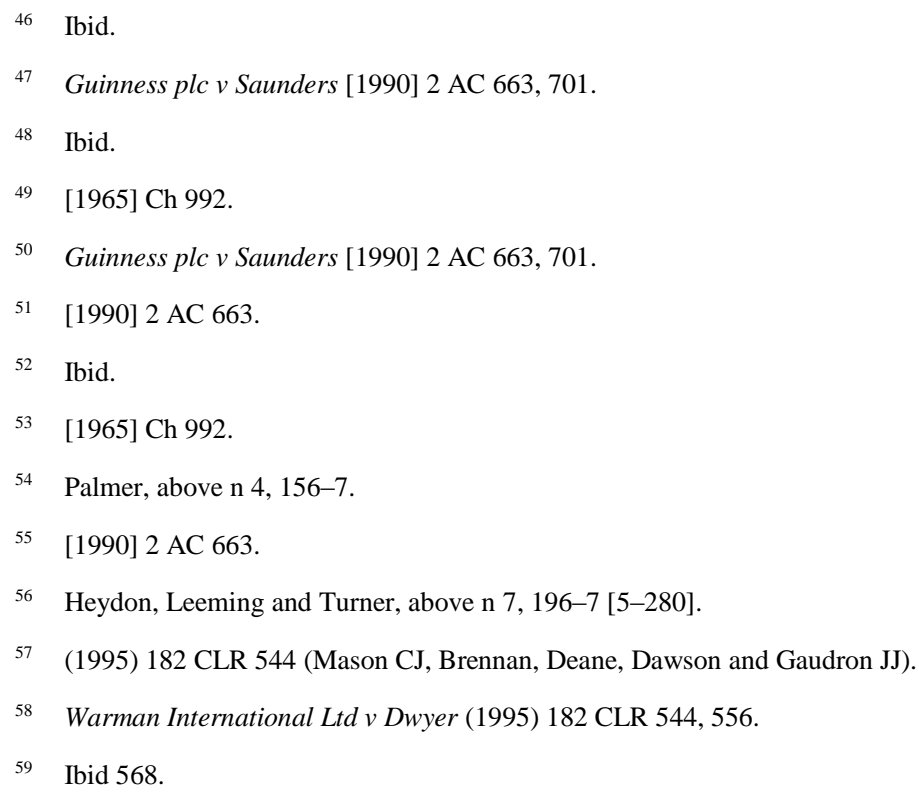


reference made to Boardman ${ }^{60}$ other than for the purpose of assessing liability for an account of profits. ${ }^{61}$ Instead, the High Court pointed out that:

In the case of a business it may well be inappropriate and inequitable to compel the errant fiduciary to account for the whole of the profit of his conduct of the business or his exploitation of the principal's goodwill over an indefinite period of time. In such a case, it may be appropriate to allow the fiduciary a proportion of the profits, depending upon the particular circumstances. That may well be the case when it appears that a significant proportion of an increase in profits has been generated by the skill, efforts, property and resources of the fiduciary, the capital which he has introduced and the risks he has taken, so long as they are not risks to which the principal's property has been exposed. Then it may be said that the relevant proportion of the increased profits is not the product or consequence of the plaintiff's property but the product of the fiduciary's skill, efforts, property and resources. This is not to say that the liability of a fiduciary to account should be governed by the doctrine of unjust enrichment, though that doctrine may well have a useful part to play; it is simply to say that the stringent rule requiring a fiduciary to account for profits can be carried to extremes and that in cases outside the realm of specific assets, the liability of the fiduciary should not be transformed into a vehicle for the unjust enrichment of the plaintiff. ${ }^{62}$

The High Court also cited O'Sullivan v Management Agency and Music Ltd, ${ }^{63}$ and noted that the appropriateness of awarding allowances would depend on the circumstances of the case, ${ }^{64}$ but also asserted that allowances for skill would be awarded 'as a general rule'. ${ }^{65}$ The problem was that the High Court did not fully explain the circumstances under which allowances should or should not be awarded for a misuse of position - it simply noted that it was important to avoid the principal's unjust enrichment. Neither did the Court expressly reject the Boardman ${ }^{66}$ principle of quantifying allowances depending on the fiduciary's conduct. As a result, the High Court introduced the unjust enrichment approach into Australian law, without rejecting the dishonesty approach. Two potential options were now open to Australian courts: dishonesty could be used either to reduce or refuse an allowance (or,

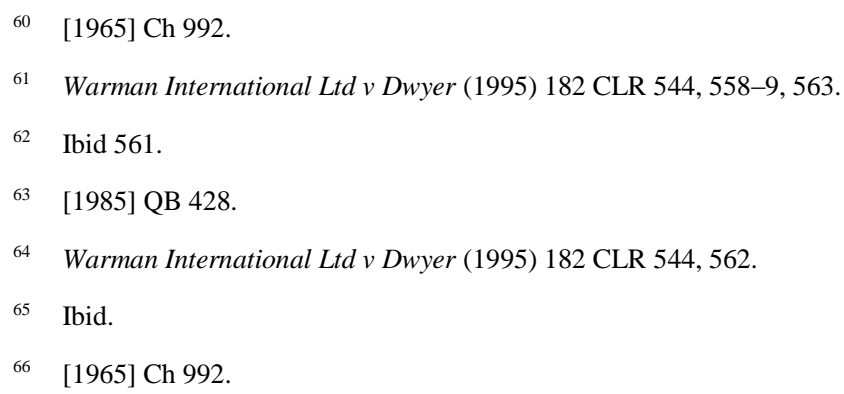


alternatively, honesty could be used to award a liberal allowance); or the nature of the fiduciary's state of mind could be ignored altogether, and allowances awarded to avoid the principal's unjust enrichment.

The new unjust enrichment approach was followed in 2000 by Lander $\mathrm{J}$ in the Supreme Court of South Australia in Edmunds v Pickering [No 4].${ }^{67}$ Pickering held a highly lucrative Abalone Authority on trust for the plaintiffs. Pickering led the plaintiffs to believe that they were required to sell their beneficial interest to him at less than market value. ${ }^{68} \mathrm{~A}$ full account of profits was not ordered, because of the Edmunds' delay. ${ }^{69}$ However, Lander J reasoned that, out of the profits for which Pickering was made to account, it was appropriate to award Pickering an allowance for his hard work in preserving the Abalone Authority. His Honour did not refer to Pickering's dishonesty, but simply cited Warman $^{70}$ as his authority for awarding an allowance to prevent the Edmunds' unjust enrichment. ${ }^{71}$

In 2005, the New South Wales Court of Appeal complicated the law in Australia by choosing to follow the Boardman-based dishonesty approach in Say-Dee Pty Ltd v Farah Constructions Pty Ltd. ${ }^{72}$ The parties were participants in a joint venture for property redevelopment. The Council rejected the redevelopment proposal because the redevelopment could proceed only if the property was amalgamated with the adjoining properties. ${ }^{73}$ Elias, the owner and operator of Farah Constructions Pty Ltd ('Farah'), breached his fiduciary obligations to Say-Dee Pty Ltd when he purchased the adjoining properties without informing them of his reasons for doing so. ${ }^{74}$ Tobias JA, with whom Mason P and Giles JA agreed, acknowledged that it was the work of Elias that had enabled Farah to acquire the adjoining properties. ${ }^{75}$ Tobias JA cited Phipps $v$ Boardman and Green \& Clara Pty Ltd v Bestobell Industries Pty Ltd [No

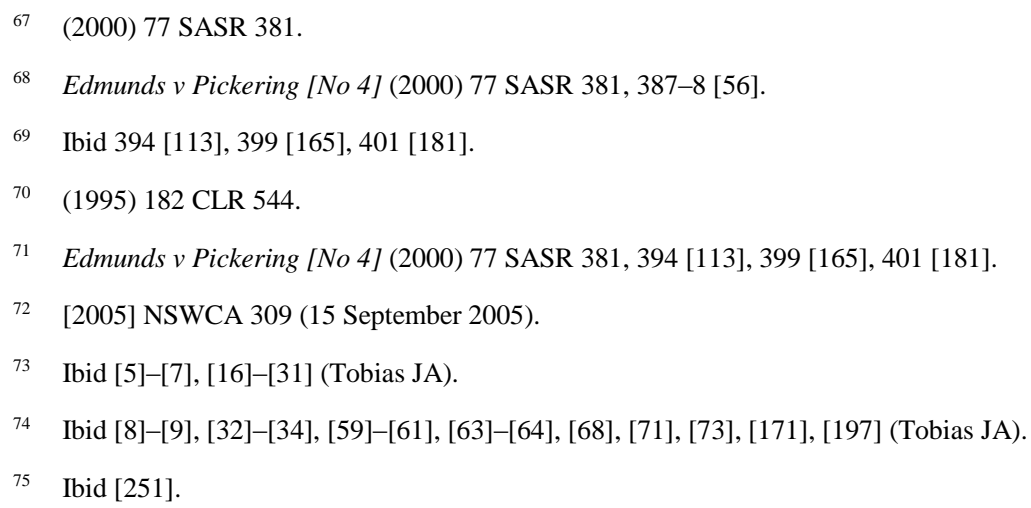


$2]^{76}$ and relied on the dishonesty approach, noting that the fiduciary's 'not insignificant degree of surreptitious conduct and bad faith' was relevant for the purpose of assessing his allowances. ${ }^{77}$ However, his Honour did not explain why he was applying the dishonesty approach, but simply noted that dishonest conduct was an important factor in quantifying the amount of allowances to be awarded. ${ }^{78}$ Tobias JA did not mention the unjust enrichment approach but explained that the main purpose of the law was to protect principals by deterring other fiduciaries from dishonestly breaching their obligations. ${ }^{79}$ Despite his dishonesty, Elias was still permitted an allowance, although it was not a liberal one. ${ }^{80}$

The confusion caused by the two available approaches is clearly demonstrated by Lym International Pty Ltd $v$ Chen ${ }^{81}$ Hamilton $\mathrm{J}$ in the Supreme Court of New South Wales followed the dishonesty approach, but the Court of Appeal ${ }^{82}$ reversed that decision and used the unjust enrichment approach. Lym International Pty Ltd ('Lym') was engaged in property development. ${ }^{83}$ The project manager, Chen, convinced one of Lym's directors to give him power of attorney over Lym. ${ }^{84} \mathrm{He}$ subsequently used this power to sell the property to himself. ${ }^{85}$ Hamilton $\mathrm{J}$ found that Chen was in a fiduciary relationship with Lym and had misused his position to gain an unfair advantage.${ }^{86} \mathrm{Chen}$ applied for an allowance for his work and skill in completing the property development. ${ }^{87}$ Hamilton $\mathbf{J}$ relied on the dishonesty approach and refused to award Chen an allowance because of his 'substantial dishonesty'. ${ }^{88}$ The case authorities cited by his Honour were limited to those supporting the dishonesty

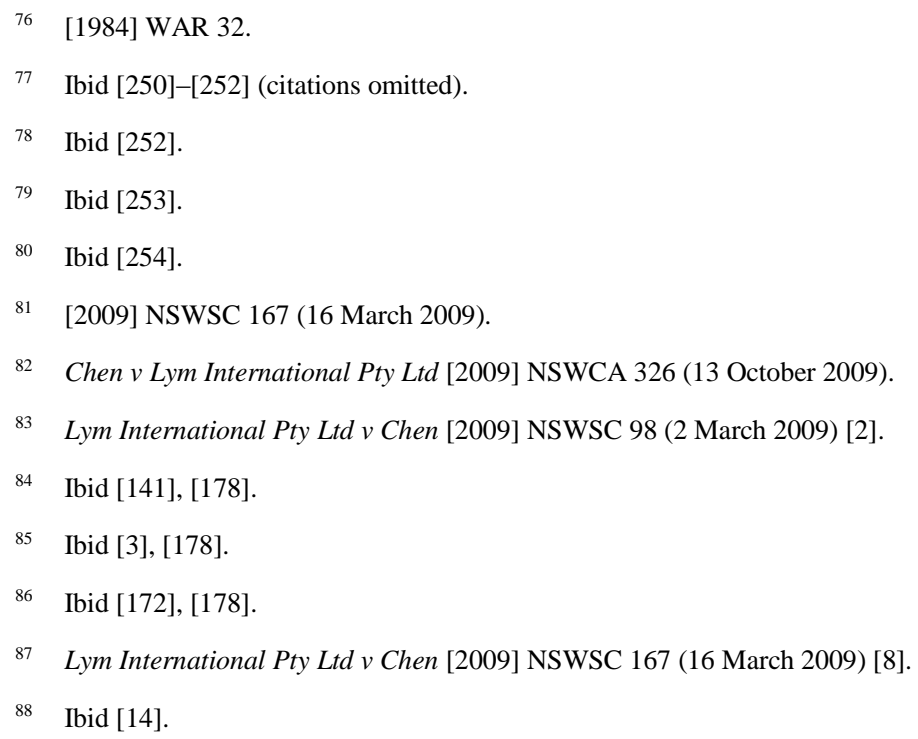


approach and the requirement to do what was practically just in all of the circumstances. ${ }^{89}$ Hamilton $\mathbf{J}$ did not explain why he was applying the dishonesty approach, nor did he refer to the availability of the more recent unjust enrichment approach. His Honour held that the refusal to award Chen an allowance was justifiable on two grounds: first, Chen's dishonesty; and secondly, because it was necessary to deter other fiduciaries from dishonestly breaching their obligations. ${ }^{90}$

This refusal to award an allowance was overturned on appeal. ${ }^{91}$ According to Young JA, with whom Allsop P and Giles JA agreed, Chen's dishonesty was not grounds to refuse an allowance. Young JA 'set out the key passage from Warman', ${ }^{92}$ applied the unjust enrichment approach and asserted that it was appropriate to award an allowance in the circumstances because it was Chen's work in improving the property that had made the profit. ${ }^{93}$ His Honour did mention that dishonesty might be relevant for the question of assessing allowances, ${ }^{94}$ but did not elaborate any further on that point. His Honour pointed out that to refuse Chen an allowance would result in Lym being unjustly enriched, because otherwise, Lym would receive the property at a vastly increased value without the financial drawback of having to develop the property itself. ${ }^{95}$ Young JA held that Chen's dishonesty did not prevent him from receiving an allowance. ${ }^{96}$

The progression of the case law shows that the courts do recognise the availability of the dishonesty and unjust enrichment approaches; however, the judges do not explain their preference for one approach over the other. The judicial reasoning is generally limited to a statement of authority supporting

\footnotetext{
89 Ibid [9]-[13], quoting United States Surgical Corporation v Hospital Products International Pty Ltd [1983] 2 NSWLR 157, 241; O'Sullivan v Management Agency and Music Ltd [1985] QB 428, 467-8 (Fox LJ); Green \& Clara Pty Ltd v Bestobell Industries Pty Ltd [No 2] [1984] WAR 32, 38 .

90 Ibid [14].

91 Chen v Lym International Pty Ltd [2009] NSWCA 326 (13 October 2009) [335] (Young JA).

92 Ibid [332]-[333], citing Warman International Ltd v Dwyer (1995) 182 CLR 544, 561; see text at footnote 62 above.

93 Ibid [333]-[335].

94 Ibid [333].

95 Ibid [335].

96 Ibid [335]-[336].
} 
the selected approach and an application of the law to the facts. ${ }^{97}$ For the courts applying the dishonesty approach, the fiduciary's dishonesty is used to justify reducing or refusing an allowance. For those courts, the need to protect the vulnerable principal and to deter breaches of obligation are the most important considerations. On the other hand, the courts that prefer the unjust enrichment approach will award allowances despite dishonesty because their focus is on preventing the principal's unjust enrichment. ${ }^{98}$ As a result of the lack of judicial reasoning underpinning the choice in approach, there is no rationale explaining precisely why a court should choose to follow one approach over the other. This means that it is impossible to predict how dishonest fiduciaries will be treated by any given court in assessing allowances. Australian courts need to adopt one of the two approaches to bring consistency, clarity and predictability to the law, but a justification for adopting one approach over the other must be found.

\section{JUSTIFYING AND ADOPTING AN APPROACH: THE AVAILABLE OPTIONS}

There are three different options for the courts in assessing whether a dishonest fiduciary should be awarded an allowance. The first option is to refuse an allowance altogether on the grounds that principals would be protected from fiduciaries breaching their obligations. The second option is to reduce the allowance in proportion with the degree of the fiduciary's dishonesty, so that the remedy reflects the equity of the case. These two options are linked to the dishonesty approach, because Boardman ${ }^{99}$ emphasised the importance of honesty or dishonesty for assessing allowances. The third option is to ignore the fiduciary's dishonesty for the purposes of allowances, instead focusing on the value of the work done in generating the profit, because anything less than a full allowance would result in the principal's unjust enrichment. This option is linked to the unjust enrichment approach from Warman. ${ }^{100}$ This Part explores the advantages and disadvantages of the three options.

\section{A Dishonesty Approach Option One: Refusing Allowances}

Under the first option, honesty would result in generous allowances, and dishonesty would result in allowances being refused altogether. Basing

\footnotetext{
97 With the possible exception of Chen v Lym International Pty Ltd [2009] NSWCA 326 (13 October 2009).

98 (1995) 182 CLR 544.

$99 \quad$ [1965] Ch 992

100 (1995) 182 CLR 544
} 
allowances on the fiduciary's conduct could be justified by the need to protect the principal. Adopting this option would bring certainty and predictability to the law both for the judges and for the parties, but would result in a potential windfall for the principal.

Fiduciaries who breach their obligations innocently are more deserving of allowances than those who deliberately exploit their position of power. ${ }^{101}$ Denying allowances to fiduciaries who have acted dishonestly will deter others from similarly breaching their obligations, because these breaches would be financially futile. According to a unanimous New South Wales Supreme Court of Appeal judgment in 1983, ${ }^{102}$ it would be unjust and inappropriate for courts to step in and rescue fiduciaries from 'the just results of [their] own gross misconduct'. ${ }^{103}$ Awarding allowances in circumstances of dishonesty unjustly rewards bad behaviour. ${ }^{104}$ Indeed, Ernest Weinrib asserts that the only possible course of action in cases where the fiduciary has wilfully disregarded the principal's rights is to deny an allowance altogether, because awarding allowances in circumstances of dishonesty condones that conduct and aggravates the injustice suffered by the principal. ${ }^{105}$ An outright denial of an allowance to dishonest fiduciaries is the only way to neutralise that injustice. ${ }^{106}$ Refusing allowances to dishonest fiduciaries will deter other fiduciaries from breaching their obligations, ${ }^{107}$ because calculated breaches take time and effort. ${ }^{108}$ Fiduciaries contemplating a breach would be aware that they would not be remunerated for their efforts, rendering a breach financially fruitless. ${ }^{109}$ Deterrence has the added benefit of protecting principals, because they are

101 Barker, above n 42, 301; Michael Bryan, 'Boardman v Phipps (1967)' in Charles Mitchell and Paul Mitchell (eds), Landmark Cases in Equity (Hart Publishing, 2012) 581, 609.

102 United States Surgical Corporation v Hospital Products Ltd [1983] 2 NSWLR 157.

103 Ibid 243, quoting A E Randall, Story on Equity (Sweet \& Maxwell, $3^{\text {rd }}$ ed, 1920) 296 [697]. See also Lym International Pty Ltd v Chen [2009] NSWSC 167 (16 March 2009) [14].

104 United States Surgical Corporation v Hospital Products Ltd [1983] 2 NSWLR 157, 243.

105 Ernest Weinrib, 'Restitutionary Damages as Corrective Justice' (2000) 1 Theoretical Inquiries in Law 1, 29. See also Scott, above n 42, 63-4; Peter Birks, 'Rights, Wrongs, and Remedies' (2000) 20 Oxford Journal of Legal Studies 1, 33.

106 Ernest Weinrib, The Idea of Private Law (Oxford University Press, 1995) 142-4.

107 Lym International Pty Ltd v Chen [2009] NSWSC 167 (16 March 2009) [14].

108 See, eg, Green \& Clara Pty Ltd v Bestobell Industries Pty Ltd [No 2] [1984] WAR 32; Warman International Ltd v Dwyer (1995) 182 CLR 544; Lym International Pty Ltd v Chen [2009] NSWSC 98 (2 March 2009).

109 Matthew Conaglen, Thomas Bull and Lars Pehrson, Fiduciary Loyalty (Hart Publishing, 2010) 81 . 
vulnerable to the deliberate exploitation of the fiduciary's position of power. ${ }^{110}$ So, if the first option would deter fiduciaries from breaching their obligations, the dishonesty approach should be adopted.

It is undeniably attractive to award allowances according to deserts, ${ }^{111}$ and this approach would certainly bring predictability and stability to the law. Honest fiduciaries would be paid, and paid well, and dishonest fiduciaries would be left out in the cold. However, Lee Aitken and Andrew Kull doubt whether the withholding of allowances deters fiduciaries from breaching their obligations. ${ }^{112}$ Therefore, if the prospect of no remuneration would not deter fiduciaries from breaching their obligations, it follows that withholding allowances would not protect the principal from calculated breaches. In addition, awarding allowances to 'good' fiduciaries and withholding them from 'bad' fiduciaries begins to look suspiciously like a punishment and reward system. ${ }^{113}$ Both Jessica Palmer and Aitken argue that rewarding a breach of obligation is inconsistent with the need to hold the fiduciary to the highest possible standard of behaviour because breaches of obligation should not be rewarded. ${ }^{114}$ Furthermore, if dishonest fiduciaries are being punished through the refusal of allowances, the first option should not be adopted, because equity and punishment are strangers. ${ }^{115}$ It is difficult to see any basis for distinguishing between honest and dishonest conduct other than for the

110 See, eg, Victoria University of Technology v Wilson (2004) 60 IPR 392.

111 Palmer, above n 4, 165; Bryan, 'Boardman v Phipps', above n 101, 608-9; Andrew Kull, 'Restitution's Outlaws' (2003) 78 Chicago-Kent Law Review 17, 32.

112 Kull, above n 111, 32; Lee Aitken, 'Reconciling "Irreconcilable Principles" — A Revisionist View of the Defaulting Fiduciary's "Generous Equitable Allowance"' (1993) 5(1) Bond Law Review 49, 60, 67, 70. See also Palmer, above n 4, 164-5.

113 Palmer, above n 4, 162-5; Aitken, 'Reconciling "Irreconcilable Principles"”, above n 112, 64; Jeremy Birch, 'Exemplary Damages for Breach of Fiduciary Duty' (2005) 33 Australian Business Law Review 429, 438. Contra: Harris v Digital Pulse Pty Ltd (2003) 56 NSWLR 298, 311 [51] (Spigelman CJ), 380-381 [329]-[330], 384 [335] (Heydon JA); Charles E F Rickett, 'Equitable Compensation: Towards a Blueprint?' (2003) 25 Sydney Law Review 31, 59.

114 Palmer, above n 4, 164-5; Aitken, 'Reconciling "Irreconcilable Principles", , above n 112, 54. See also Meinhard v Salmon, 249 NY 458, 464 (Cardozo CJ) (1928); Warman International Ltd v Dwyer (1995) 182 CLR 544, 557.

115 Maguire v Makaronis (1996) 188 CLR 449, 496 (Kirby J); Harris v Digital Pulse Pty Ltd (2003) 56 NSWLR 298, 422 [470] (Heydon JA); Rickett, 'Understanding Remedies', above n 16,617 . 
purpose of penalising dishonesty and rewarding honesty, ${ }^{116}$ and so this option should not be adopted.

\section{B Dishonesty Approach Option Two: Reducing Allowances}

The second option supported by the dishonesty approach uses the fiduciary's dishonesty to reduce the allowance. ${ }^{117}$ This option would allow the courts to exercise their discretion and would reflect the flexibility of equitable remedies.

The flexibility of equity means that the remedy is adjusted according to the circumstances of the case. Under the second option, the fiduciary's conscience is relevant in determining the remedy. If there is dishonesty, this factor is weighed against the other circumstances to determine 'where the equities lie ${ }^{118}$ to reach a just response. ${ }^{119}$ In Harris v Digital Pulse Pty Ltd,${ }^{120}$ Heydon JA said that the court had the power to award an allowance in its discretion, but maintained that the burden of satisfying the court that an allowance should be awarded lay with the fiduciary. This burden could be discharged if the fiduciary could show 'an absence of grave misconduct' on their part. ${ }^{121}$ Blanchard and Tipping JJ in Chirnside v Fay ${ }^{122}$ pointed out that the fiduciary's conduct would affect the liberality of the allowance, but added that all of the circumstances must be taken into account to reach a just result. ${ }^{123}$ The scales may tip in the fiduciary's favour if 'the prime source of the profit' ${ }^{124}$ was caused by their efforts. It would be unjust for the principal to accept the benefit

\footnotetext{
116 Aitken, 'Reconciling "Irreconcilable Principles"', above n 112, 64.

117 G E Dal Pont and D R C Chalmers, Equity and Trusts in Australia (Lawbook, $4^{\text {th }}$ ed, 2007) 920 [34.130].

118 Ibid.

119 O'Sullivan v Management Agency and Music Ltd [1985] QB 428, 458-9 (Dunn LJ), 468-9 (Fox LJ), 472-3 (Waller LJ); see also Devonshire, Account of Profits, above n 7, 59-60 [3.3.4].

120 (2003) 56 NSWLR 298.

121 Harris v Digital Pulse Pty Ltd (2003) 56 NSWLR 298, 384 [335]-[336] (Heydon JA). See also Chirnside v Fay [2006] NZSC 68 (6 September 2006) 158 [142] (Blanchard and Tipping $\mathrm{JJ})$.

122 [2006] NZSC 68 (6 September 2006).

123 Chirnside v Fay [2006] NZSC 68 (6 September 2006) 153 [122], 154 [127] (Blanchard and Tipping JJ). See also Bailey v Namol Pty Ltd (1994) 53 FCR 102, 112.

124 Dal Pont and Chalmers, above n 117, 920 [34.130].
} 
of the fiduciary's work in circumstances where the profit could not have been made but for the fiduciary's efforts. ${ }^{125}$

On the other hand, because it was the fiduciary's breach that created the profit in the first place, it follows that the profit could not have been made but for the breach. In O'Sullivan $v$ Management Agency and Music Ltd, ${ }^{126}$ it was recognised that when the profits were the result of the fiduciary's work and skill, it would be unjust to deny that effort - even where the fiduciary had acted dishonestly. ${ }^{127}$ James Edelman and Jeremy Birch claim that it would be impossible for a dishonest fiduciary to discharge the burden of proving that it would be inequitable to refuse an allowance. ${ }^{128}$ Therefore, if dishonest fiduciaries could never discharge the onus of proof, it follows that they would never receive an allowance, even though it was their work that generated the profit. In truth then, the practical effect of adopting the second option would be identical to the first. Honest fiduciaries would be remunerated, and dishonest fiduciaries would not. This means that option two should not be adopted for the same reasons given for rejecting option one, namely, rewarding honest breaches of obligation and penalising dishonest breaches.

\section{Option Three: Allowances to Prevent Unjust Enrichment}

The third option follows the unjust enrichment approach. Courts would disregard the fiduciary's dishonesty and quantify the allowance according to the value of the fiduciary's work. Adopting this approach would restore balance to the parties by returning the appropriate portions of the profit to each of the respective parties. Because the principal seeks equity from the courts when asking for an account of profits, the principal should do equity in return by recognising the value of the fiduciary's work through an allowance. ${ }^{129}$

The unjust enrichment approach highlights the importance of the fiduciary's work and skill in generating the profit. Under this approach, it is possible to award allowances in all cases of fiduciary breach using the principles of unjust enrichment and corrective justice. Corrective justice reverses wrongful gains.

125 O'Sullivan v Management Agency and Music Ltd [1985] QB 428, 458-9 (Dunn LJ), 468-9 (Fox LJ), 472-3 (Waller LJ).

126 [1985] QB 428.

127 Ibid 458-9 (Dunn LJ), 468-9 (Fox LJ), 472-3 (Waller LJ).

128 Birch, above n 113, 439; James Edelman, ‘A “Fusion Fallacy” Fallacy?' (2003) 119 Law Quarterly Review 375, 376-7. See also K Mason, J W Carter and G J Tolhurst, Mason and Carter's Restitution Law in Australia (LexisNexis Butterworths, $2^{\text {nd }}$ ed, 2008) 705 [1736].

129 Devonshire, Account of Profits, above n 7, 73-4 [4.1], 80 [4.2.2]. 
An account of profits reverses the gains made from the fiduciary's breach of obligation, by taking the profits attributable to the breach and returning them to the principal. ${ }^{130}$ When an allowance is sought, corrective justice would simply deduct the value of the fiduciary's work from the profit, before returning the bulk to the principal. Andrew Burrows argues that the overall profit comprises two separate values. The first is the value of the work done in generating the profit, and it 'belongs' to the fiduciary because it is attributable to their efforts. The second value is the remainder of the profit, and this 'belongs' to the principal because it is attributable to the breach. Permitting the principal to retain both values would result in unjust enrichment because the first value 'belongs' to the fiduciary, not the principal. ${ }^{131}$ Michael Bryan and Kull both extend this argument by pointing out that the principal's unjust enrichment can be reversed by using the principles of corrective justice. Corrective justice restores balance to the parties by removing the value of the fiduciary's work from the principal and restoring it to the fiduciary. ${ }^{132}$ Because the fiduciary's work generated the profits, it would be inequitable for the principal to deny that value and refuse to remunerate the fiduciary. ${ }^{133}$

On the other hand, a blanket award of allowances for all cases of breach would arguably erode the core duty of loyalty, because it could act as a motivation for breaches of obligation. The duty of loyalty requires fiduciaries to conduct themselves at a 'level higher than that trodden by the crowd'. ${ }^{134}$ Mason P, Kit Barker and Kull have all argued that fiduciaries who breach in bad faith have failed to meet the required standard of behaviour, and so should not be

130 Miller, 'Justifying Fiduciary Remedies', above n 16, 572; Weinrib, 'Restitutionary Damages', above n 105, 16-18; Duncan Sheehan, 'Subtractive and Wrongful Enrichment: Identifying Gain in the Law of Restitution' in Charles Rickett (ed), Justifying Private Law Remedies (Hart Publishing, 2008) 333, 347-8.

131 Andrew Burrows, The Law of Restitution (Oxford University Press, $3^{\text {rd }}$ ed, 2011) 634. See also Graham Virgo, 'Restitutionary Remedies for Wrongs: Causation and Remoteness' in Charles Rickett (ed), Justifying Private Law Remedies (Hart Publishing, 2008) 301, 304, 310$11,325-6$.

132 Bryan, 'Boardman v Phipps', above n 101, 608; Kull, above n 111, 17-18, 27-9; Michael Bryan, 'Equitable Relief from Forfeiture: Performance or Restitution?' in Charles Rickett (ed), Justifying Private Law Remedies (Hart Publishing, 2008) 363, 366.

133 Re Jarvis; Edge v Jarvis [1958] 1 WLR 815, 820; Phipps v Boardman [1964] 1 WLR 993, 1018; Devonshire, Account of Profits, above n 7, 73-4 [4.1], 80 [4.2.2].

134 Meinhard v Salmon, 249 NY 458, 464 (Cardozo CJ) (1928), quoted in Warman International Ltd v Dwyer (1995) 182 CLR 544, 557. 
remunerated. ${ }^{135}$ In her Honour's dissenting judgment in the New Zealand case, Chirnside v Fay, Elias CJ argued that to award allowances in circumstances of dishonesty encourages fiduciaries to breach their obligations, and erodes the core duty of loyalty. ${ }^{136}$ The argument that fiduciaries who dishonestly breach their obligations actively seek to promote their own interests to the detriment of their principal's finds support in some Australian case law. ${ }^{137}$ Aitken asserts that to hold that principals would be unjustly enriched clashes with equity's insistence on holding the fiduciary to the highest possible standard and its role in protecting the vulnerable principal. ${ }^{138}$

The argument in favour of promoting the core duty of loyalty is very similar to the reasoning supporting the first option: honest fiduciaries would be paid, but dishonest ones would not, because they would otherwise be encouraged to place their interests ahead of their principal's. Birch argues that the fiduciary's dishonesty does not affect the enrichment of the principal, because the value of the work is not altered by the presence of dishonesty. ${ }^{139}$ For example, the property redevelopment by Chen in Lym International Pty Ltd $v$ Chen ${ }^{140}$ was not rendered any less valuable to Lym because of Chen's bad faith. If allowances are based in counter-restitution and awarded to prevent the principal's unjust enrichment, the fiduciary's dishonesty should be irrelevant for quantifying the effort that generated the profit. ${ }^{141}$ If the prevention of unjust enrichment via counter-restitution will 'do equity', it follows that in every case of default, the fiduciary would be entitled to an allowance for their work. ${ }^{142}$

This Part has argued that the first two options based on the dishonesty approach would not achieve their objectives. There is no evidence that fiduciaries are deterred by the prospect of not being remunerated. Awarding allowances to

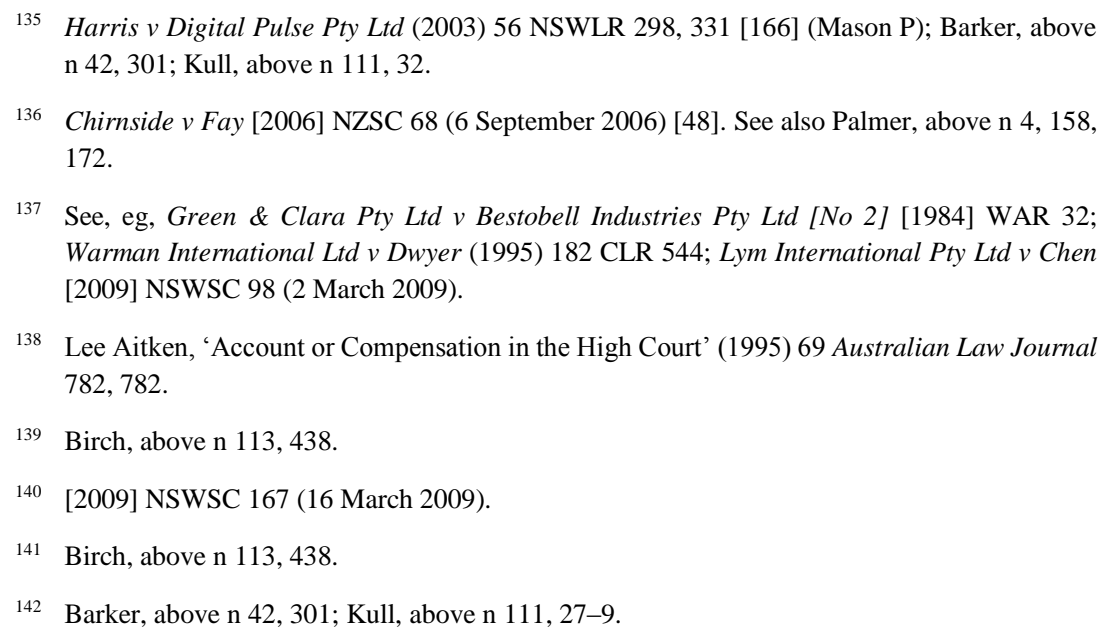


reward 'good' behaviour contradicts the standard of conduct required of fiduciaries, and to withhold allowances on the basis of dishonesty arguably punishes bad conduct. It follows that the dishonesty approach should not be adopted. Option three is the most attractive solution because it would result in certainty and predictability in the law and would restore balance to the parties. For these reasons, the unjust enrichment approach should be adopted by the courts when asked to award allowances to defaulting fiduciaries.

\section{CONCLUSION}

This article has argued that the High Court of Australia should reject the dishonesty approach offered by Boardman, ${ }^{143}$ and instead adopt the unjust enrichment approach presented by Warman, ${ }^{144}$ because this reflects corrective justice. The principal would receive the profits attributable to the primary breach of obligation, and the fiduciary would receive the portion of the profit that represented the value of their work. Ignoring the fiduciary's dishonesty in the assessment of allowances would bring certainty and predictability into the law, and would advance the equitable maxim that those who seek equity must do equity. Moreover, requiring a person who is willing to accept the benefit produced by another's work and skill to pay for that work also accords with ordinary commercial expectations and common sense intuitions about justice.

143 [1965] Ch 992.

144 (1995) 182 CLR 544. 